\title{
Genetic influence on serum 25- hydroxyvitamin D concentration in Korean men: a cross-sectional study
}

\author{
Songhwa Choi ${ }^{1}$, Hyeonyoung Ko ${ }^{2}$, Kayoung Lee 3 , Joohon Sung ${ }^{4}$ and Yun-Mi Song ${ }^{1 *}$ (D)
}

\begin{abstract}
Background: Hypovitaminosis D is prevalent worldwide. It is more prevalent in Eastern Asia region, including Korea. In addition to various environmental factors that influence serum 25 -hydroxyvitamin $\mathrm{D}(25(\mathrm{OH}) \mathrm{D})$ concentration, genetic influence also plays a significant role based on studies estimating the heritability of $25(\mathrm{OH}) \mathrm{D}$ in non-Asian populations. The objective of this study was to determine the genetic influence on serum $25(\mathrm{OH}) \mathrm{D}$ concentration in Korean men using the twin and family data.

Methods: A total of 1126 Korean male adult twins and family members from the Healthy Twin Study with serum 25(OH)D measurement were included in this cross-sectional study. Intraclass correlation coefficients (ICCS) and heritability were calculated by mixed linear regression analysis and quantitative genetic analysis after adjusting for environmental and lifestyle factors.
\end{abstract}

Results: Mean ( \pm standard deviation; SD) of serum 25(OH)D concentration was $15.34 \pm 6.18 \mathrm{ng} / \mathrm{ml}$. The prevalence of vitamin D insufficiency was $19.8 \%$ and that of vitamin D deficiency was $77.9 \%$. After adjusting for age, the highest ICC (0.61) was observed for monozygotic twin pairs while the lowest ICC (0.31) was found for father-son pairs. Age-adjusted heritability was estimated to be $58 \%$. When physical activity, multivitamin intake and season of blood sampling were further considered, the ICC and heritability did not materially change. In the sensitivity analysis after excluding known multivitamin users, age-adjusted heritability was reduced to $44 \%$.

Conclusions: In our study of Korean male twins and family members, heritability of $25(\mathrm{OH}) \mathrm{D}$ was moderately high. This supports the finding that genetic factors have significant influence on vitamin D status.

Keywords: Vitamin D, Genetics, Twin study, Ethnicity, Korea

\section{Background}

Vitamin $\mathrm{D}$ is one of the most important nutrients associated with health status. Vitamin D deficiency, also known as hypovitaminosis $\mathrm{D}$, is associated with many clinically important diseases, including osteoporosis, cardiovascular diseases, diabetes mellitus, and cancers [1-5]. Serum 25-hydroxyvitamin D $(25(\mathrm{OH}) \mathrm{D})$ is a storage metabolite form of vitamin $\mathrm{D}$. Vitamin $\mathrm{D}$ insufficiency is defined when serum $25(\mathrm{OH}) \mathrm{D}$ concentration is low $(20-29 \mathrm{ng} / \mathrm{ml})$ while vitamin D deficiency is considered when its concentration is very

\footnotetext{
* Correspondence: yunmisong@skku.edu

${ }^{1}$ Department of Family Medicine, Samsung Medical Center, Sungkyunkwan

University School of Medicine, Irwon-ro 81, Gangnamgu, Seoul 06351

135-710, South Korea

Full list of author information is available at the end of the article
}

low $(<20 \mathrm{ng} / \mathrm{ml})$ [6]. It has been estimated that around one billion people worldwide have insufficient concentrations of vitamin D [6]. In the USA, the prevalence of $25(\mathrm{OH}) \mathrm{D}$ insufficiency $(<30 \mathrm{ng} / \mathrm{ml})$ has increased from 69\% during 1988-1994 to $76 \%$ during 2001-2006 [7].

The major source of vitamin $\mathrm{D}$ is cutaneous synthesis through sunlight exposure. Cholecalciferol $\left(25(\mathrm{OH}) \mathrm{D}_{3}\right)$ is a form of vitamin D mainly synthesized in the skin. Its association with ethnicity and degree of skin pigmentation has been well documented in previous reports [8-10]. A study using the National Health and Nutrition Examination Survey (NHANES) III data by Zadshir et al. [10] has revealed that Caucasians have higher mean concentrations of $25(\mathrm{OH}) \mathrm{D}_{3}$ than Hispanics

(C) The Author(s). 2018 Open Access This article is distributed under the terms of the Creative Commons Attribution 4.0 International License (http://creativecommons.org/licenses/by/4.0/), which permits unrestricted use, distribution, and 
or Black people regardless of age group. People who have the darkest color of skin due to high melanin pigmentation have the lowest concentration of mean $25(\mathrm{OH}) \mathrm{D}_{3}$. The prevalence of hypovitaminosis D $(\leq 28 \mathrm{ng} / \mathrm{ml})$ was $81 \%$ in Black males, $56 \%$ in Hispanic males, and $34 \%$ in White males [10].

The skin of Asians, including that of Koreans, is more pigmented than Caucasians' skin but less pigmented than Black people. Thus, one could easily hypothesize that Asians would show a somewhat similar rate of vitamin D deficiency to Hispanics. However, a study analyzing the Korean National Health and Nutritional Examination Survey (KNHANES) data revealed that only $13.2 \%$ of Korean men and $6.7 \%$ of Korean women had sufficient concentrations of serum 25(OH)D ( $\geq 30 \mathrm{ng} /$ $\mathrm{ml}$ ) in 2010 [11]. High prevalence of vitamin D insufficiency was also documented in a multicenter study conducted in China, where only $5.4 \%$ of all participants had sufficient $25(\mathrm{OH}) \mathrm{D}$ concentrations $(>30 \mathrm{ng} / \mathrm{ml})$ in 2013 [12]. In a population-based cohort study in Japan, only $17.5 \%$ of the study participants had sufficient concentrations of $25(\mathrm{OH}) \mathrm{D}(\geq 30 \mathrm{ng} / \mathrm{ml})$ [13]. Such high prevalence of hypovitaminosis D commonly seen in several Eastern Asian countries suggests that some factors other than skin pigmentation might play important roles in determining serum vitamin D concentrations. These factors may include genetic and cultural factors that affect sun exposure and vitamin D intake. Several previous studies have investigated the effect of genetic factors on vitamin D status $[8,14-20]$. However, estimated heritability in these studies varied widely from 23 to $80 \%$. In addition, studies on heritability of vitamin $\mathrm{D}$ in Asian population are very scarce, with only one study on Chinese adolescent twins [14]. Studies on Asian adults have not been reported yet. Therefore, the objective of the present study was to investigate genetic influence on vitamin D status in Korean male adult twins and their family members by estimating the heritability of serum $25(\mathrm{OH}) \mathrm{D}$ concentration considering their relevant lifestyle factors.

\section{Methods}

\section{Study participants}

We selected study subjects from the participants of the Healthy Twin Study. Details on the study design and protocols of the Healthy Twin Study have been described in a previous article [21]. In short, the Healthy Twin Study is a community-based cohort study conducted from April 2005 to April 2014. It recruited the same sex Korean adult twins ( $\geq 30$ years of age) and their first-degree family members from the general population in order to investigate the quantitative loci of complex traits, as well as the role of environment in the etiology of complex diseases, through nationwide advertisement and mailing to the members of the Korean Twin-Family Register. The study participants provided blood samples and completed detailed questionnaires about lifestyle and epidemiologic information. Among 3489 persons who have participated in the Healthy Twin Study at the first time between December 2005 and December 2012, a total of 1131 Korean men were included in the study, after excluding females and participants who were devoid of serum 25(OH)D measurement. Among these participants, we excluded five participants for the following reasons: undetectable serum $25(\mathrm{OH}) \mathrm{D}$ concentration $(n=4)$ and inadequate blood sample $(n=1)$. As a result, 1126 participants from 425 families were included in the analyses, which was comprised of 292 monozygotic twin pairs, 68 dizygotic twin pairs, and 766 non-twin individuals (see Additional file 1). Written informed consent was obtained from all participants of this study. Institutional Review Board of each participating center approved the study protocol.

\section{Measurements}

Blood sampling was performed for all participants in the morning (around 10 a.m.) after an overnight fast. Serum was immediately separated and stored at $-70^{\circ} \mathrm{C}$. Serum $25(\mathrm{OH}) \mathrm{D}$ concentrations of all study participants were measured by chemiluminescence immunoassay using LIAISON $^{\circ}$ XL (DiaSorin, Italy) after thawing the frozen serum in a central laboratory. The assay could not discern between D2 and D3 forms of 25(OH)D. Serum concentration of calcium in fresh sera was measured with commercial kit for calcium (colorimetry) on ADVIA 1650 (Siemens, Germany).

Body weight and height were measured twice by trained research assistants according to the standardized protocol. Body mass index (BMI) was calculated by average weight divided by average height squared $\left(\mathrm{kg} / \mathrm{m}^{2}\right)$.

Information on smoking status, alcohol consumption, and physical exercise was collected using a selfadministered questionnaire. Smoking status was assessed by using two questions: "have you smoked more than 20 packs of cigarette (400 cigarettes) all the while?" and "are you still smoking?". Then, study participants were categorized into three groups: never smokers, past smokers, and current smokers. Alcohol consumption status was categorized into two groups (current drinker or non-drinker) by the response to the following two questions; "have you ever drunk alcohol?" and "do you still drink alcohol?" Physical exercise was categorized into three groups by the frequency of exercise per week: less than once per week, one to approximately two times per week, and three or more times per week. For categorization of physical exercise, two questions were asked: "do you regularly exercise to the point of sweating?" and "how many times do you exercise per week?" 
To find out whether the study participant had been taking multivitamins, the following question was used: "how many pills of multivitamin a week do you take?" We defined seasons into either winter or summer based on the month of blood sampling: winter (from November to April) and summer (from May to October).

In the Healthy Twin Study, zygosity was verified by using 16 short tandem repeat markers including sexdetermining marker (PekinElmer's AmpFISTR ${ }^{\circ}$, Norwalk, CT) for $67 \%$ of twin pairs and a self-administered zygosity questionnaire for $33 \%$ of twin pairs. The zygosity questionnaire showed $94.3 \%$ accuracy in ascertainment of zygosity compared to that confirmed by the short tandem repeat markers kit [22].

\section{Statistical analyses}

The study participants were categorized according to tertiles of serum 25(OH)D concentration. Characteristics of participants between tertile groups were compared using chi-square test for categorical variables and analysis of covariance for continuous variables with consideration of age. For categorical variables, direct age standardization was done using Korean male population distribution in the year of 2010 as standard population. The trend of serum $25(\mathrm{OH}) \mathrm{D}$ was examined according to age distribution using linear regression analysis. Intraclass correlation coefficients (ICCs) between pairs of twins, siblings, and father-son were estimated using mixed linear regression model. Dizygotic twins are genetically similar to non-twin siblings. Therefore, they were included in siblings' group for statistical analyses. Quantitative genetic analysis [23, 24] was performed to estimate the heritability of serum $25(\mathrm{OH}) \mathrm{D}$ concentration (the proportion of total phenotypic variance explained by additive genetic factors). Variance component approach was applied to separate total phenotypic variation $\left(6 \mathrm{p}^{2}\right)$ into additive genetic component $\left(6 \mathrm{a}^{2}\right)$, unmeasured environmental component $\left(6 \mathrm{e}^{2}\right)$, and unmeasured shared environmental components $\left(6 \mathrm{c}^{2}\right)$. This model assumes that the effects of environmental factors are common for members of a family while three variance components $\left(6 \mathrm{a}^{2}, 6 \mathrm{e}^{2}, 6 \mathrm{c}^{2}\right)$ are independent of each other. Therefore, total phenotypic variance becomes the sum of these three factors $\left(6 p^{2}=6 a^{2}+6 e^{2}+6 c^{2}\right)$. Heritability can be estimated as the proportion of observed phenotypic variance attributed to additive genetic component $\left(6 \mathrm{a}^{2} / 6 \mathrm{p}^{2}\right)$.

To examine the influence of multivitamin intake on heritability estimation, we performed sensitivity analysis after excluding participants who reported of using multivitamin supplements. We included the participants who did not take multivitamin supplements and those who did not respond to the relevant questionnaire, assuming these people as non-regular users of any nutritional supplements. ICCs and heritability were calculated as described above.

Analyses were conducted using PAWS Statistics (ver. 21.0 for Windows; SPSS, Chicago, Illinois), SAS version 9.3 (SAS Institute Inc., Cary, NC, USA), and Sequential Oligogenic Linkage Analysis Routines (SOLAR) Eclipss version 7.6.4 (Southwest Foundation for Biomedical Research, San Antonio, TX, USA).

\section{Results}

The mean ( \pm standard deviation, SD) serum $25(\mathrm{OH}) \mathrm{D}$ concentration was $15.34 \pm 6.18 \mathrm{ng} / \mathrm{ml}$. A total of $19.8 \%$ of all participants had insufficient concentration of serum $25(\mathrm{OH}) \mathrm{D}$ while $77.9 \%$ of all participants had deficient concentration of serum 25(OH)D.

Figure 1 shows how mean serum 25(OH)D concentration is distributed throughout the year according to the time of blood sampling. The highest mean 25(OH)D concentration $(19.34 \mathrm{ng} / \mathrm{ml})$ appeared in participants whose blood was drawn in September (late summer season) whereas the lowest concentration $(10.10 \mathrm{ng} / \mathrm{ml})$ was seen in participants whose blood was drawn in January (winter season). Mean $( \pm \mathrm{SD}) 25(\mathrm{OH}) \mathrm{D}$ concentrations in the winter and summer were $12.54 \pm 5.26 \mathrm{ng} / \mathrm{ml}$ and $16.94 \pm 6.10 \mathrm{ng} / \mathrm{ml}$, respectively $(P<0.001)$.

Characteristics of all study participants $(n=1126)$ by tertile distribution of serum 25(OH)D concentration with trend results are shown in Table 1 . The mean age

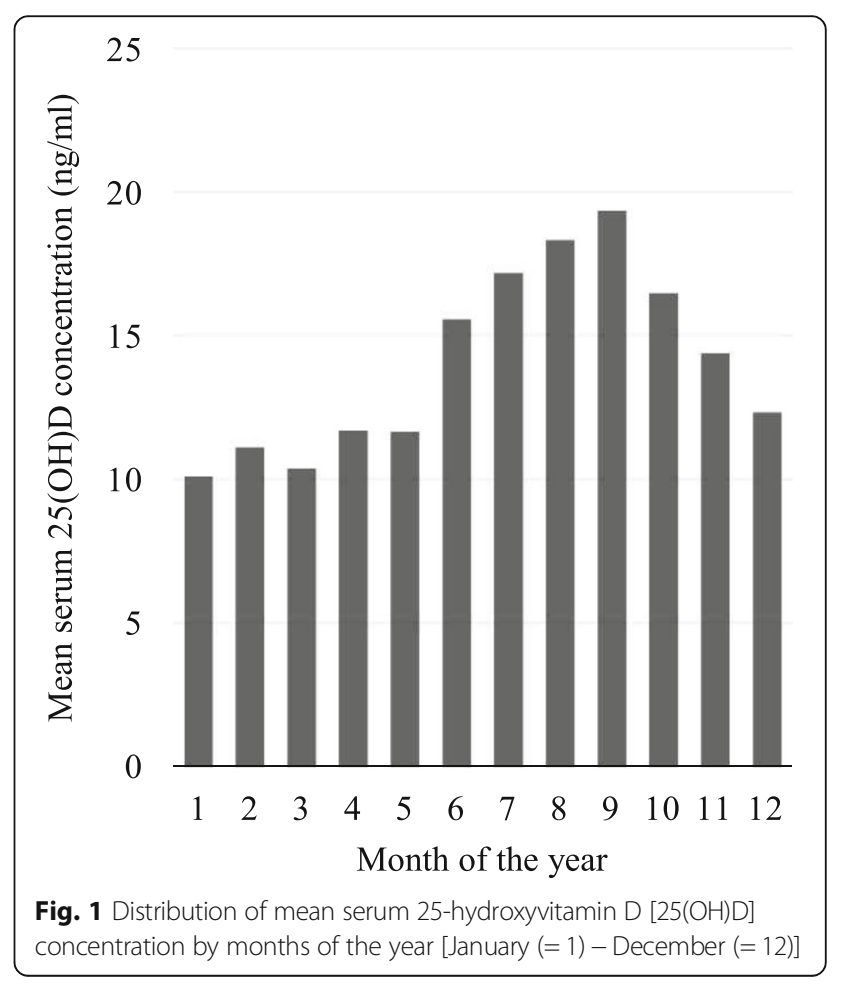


was increased significantly from the lowest $25(\mathrm{OH}) \mathrm{D}$ tertile group to the highest tertile group. The proportion of multivitamin users tended to be higher among participants with higher serum 25(OH)D concentration ( $p$ for trend $<0.001$ ). Although there were significant differences in smoking status, alcohol consumption, and the frequency of regular physical exercise between $25(\mathrm{OH}) \mathrm{D}$ tertile groups and the least percentage of current smokers or alcohol drinkers was observed in the highest $25(\mathrm{OH}) \mathrm{D}$ tertile group, no specific trends were found. Body mass index or serum calcium concentration did not differ significantly between 25(OH)D tertile groups.

Figure 2 shows distribution of mean serum 25(OH)D concentration and the prevalence of vitamin D insufficiency or deficiency by different age groups. As the age of participant increased, mean serum $25(\mathrm{OH}) \mathrm{D}$ concentration tended to increase $\left(R^{2}=0.032, p\right.$ for trend $\left.<0.001\right)$ (Fig. 2a). The highest mean concentration of $25(\mathrm{OH}) \mathrm{D}$ $(17.85 \mathrm{ng} / \mathrm{ml})$ was found in the oldest age group $(\geq 70$ years) while the lowest mean concentration $(10.58 \mathrm{ng} / \mathrm{ml})$ was found in the youngest age group ( $<20$ years). As can be inferred from this trend of $25(\mathrm{OH}) \mathrm{D}$ concentration by age, the prevalence of hypovitaminosis $\mathrm{D}$ tended to decrease with increase in age (Fig. 2b).

ICCs between various types of intrafamilial pairs and estimated heritability of serum $25(\mathrm{OH}) \mathrm{D}$ concentration are presented in Table 2. Only monozygotic twin pairs showed moderately high correlation: 0.61 in age-adjusted analysis and 0.53 in multivariable-adjusted analysis.
Heritability of $25(\mathrm{OH}) \mathrm{D}$ was estimated to be moderately high: $58 \%$ in age-adjusted analysis and $51 \%$ in multivariable-adjusted analysis. Covariates included in these analyses were found to explain about $16 \%$ of the total variance. In all models, unmeasured shared environmental components $\left(6 c^{2}\right)$ had negligible influence on phenotypic variance.

When we repeated the analysis after excluding the participants who reported the usage of multivitamin supplements, the estimated heritability was reduced to $44 \%$ in age-adjusted analysis and $40 \%$ in multivariableadjusted analysis (Table 3).

\section{Discussion}

In these relatively healthy Korean men, the overall prevalence of vitamin $\mathrm{D}$ insufficiency and deficiency (serum $25(\mathrm{OH}) \mathrm{D}<30 \mathrm{ng} / \mathrm{ml}$ ) was found to be very high (97.7\%). Age, smoking, alcohol consumption, physical exercise, multivitamin intake, and season of blood sampling were identified as factors associated with serum 25(OH)D concentration. The heritability in Korean male twins and their family members was moderately high after considering covariates. To our best knowledge, this is the first study that uses data from twins and family members to determine the heritability of vitamin D status in Eastern Asian adult population. We considered and included covariates known to be associated with serum $25(\mathrm{OH}) \mathrm{D}$ concentration in previous studies and made adjustment for these covariates to have more accurate estimation of heritability.

Table 1 Characteristics of study participants

\begin{tabular}{|c|c|c|c|c|}
\hline \multirow[t]{2}{*}{ Variables } & \multicolumn{3}{|c|}{ 25-Hydroxyvitamin D, ng/ml } & \multirow{2}{*}{$\begin{array}{l}P \\
\text { trend }^{\mathrm{a}}\end{array}$} \\
\hline & $\leq 11.7(n=374)$ & $11.8 \sim 17.2(n=374)$ & $\geq 17.3(n=378)$ & \\
\hline 25-Hydroxyvitamin D, ng/ml & $9.07 \pm 0.15^{b}$ & $14.47 \pm 0.14$ & $22.42 \pm 0.14$ & $<0.001$ \\
\hline Age, year & $40.98 \pm 14.23$ & $44.47 \pm 13.78$ & $47.21 \pm 14.37$ & $<0.001$ \\
\hline Body mass index, $\mathrm{kg} / \mathrm{m}^{2}$ & $24.57 \pm 0.16$ & $24.65 \pm 0.15$ & $24.29 \pm 0.15$ & 0.152 \\
\hline \multicolumn{5}{|l|}{ Smoking } \\
\hline Current-smoker & $40.34[181]^{\mathrm{c}}$ & $43.81[162]$ & $28.52[134]$ & \\
\hline Past-smoker & $20.80[87]$ & $19.96[93]$ & $25.90[132]$ & $<0.001$ \\
\hline Never-smoker & 38.86 [105] & $36.23[118]$ & $45.58[112]$ & \\
\hline Current-drinker & 77.44 [295] & $83.40[301]$ & $62.87[291]$ & $<0.001$ \\
\hline \multicolumn{5}{|l|}{ Physical exercise } \\
\hline$\geq 3$ times/week & $20.26[69]$ & $29.43[84]$ & $22.42[106]$ & \\
\hline $1 \sim 2$ times/week & $18.97[59]$ & $13.31[63]$ & $14.78[63]$ & $<0.001$ \\
\hline$<1$ time/week & $60.77[233]$ & $57.25[217]$ & $62.80[198]$ & \\
\hline Multivitamin intaker & $14.2[59]$ & 20.4 [93] & $21.6[94]$ & $<0.001$ \\
\hline Calcium, mmol/L & $2.37 \pm 0.01$ & $2.36 \pm 0.01$ & $2.36 \pm 0.01$ & 0.072 \\
\hline
\end{tabular}

For some study participants, information was not available for smoking status $(n=2)$, alcohol consumption $(n=1)$, physical exercise $(n=34)$, or multivitamin intake $(n=10)$

${ }^{a} P$ values for trend were obtained by linear-by-linear association of chi-square test for categorical variables or by linear regression analysis for continuous variables ${ }^{b}$ Data were presented as age-adjusted mean \pm standard error for continuous variables. Age-adjusted mean values were calculated by analysis of covariance test

'Data were presented as number (age-standardized percentage) for categorical variables. $n$ in brackets indicates the number of study participants 

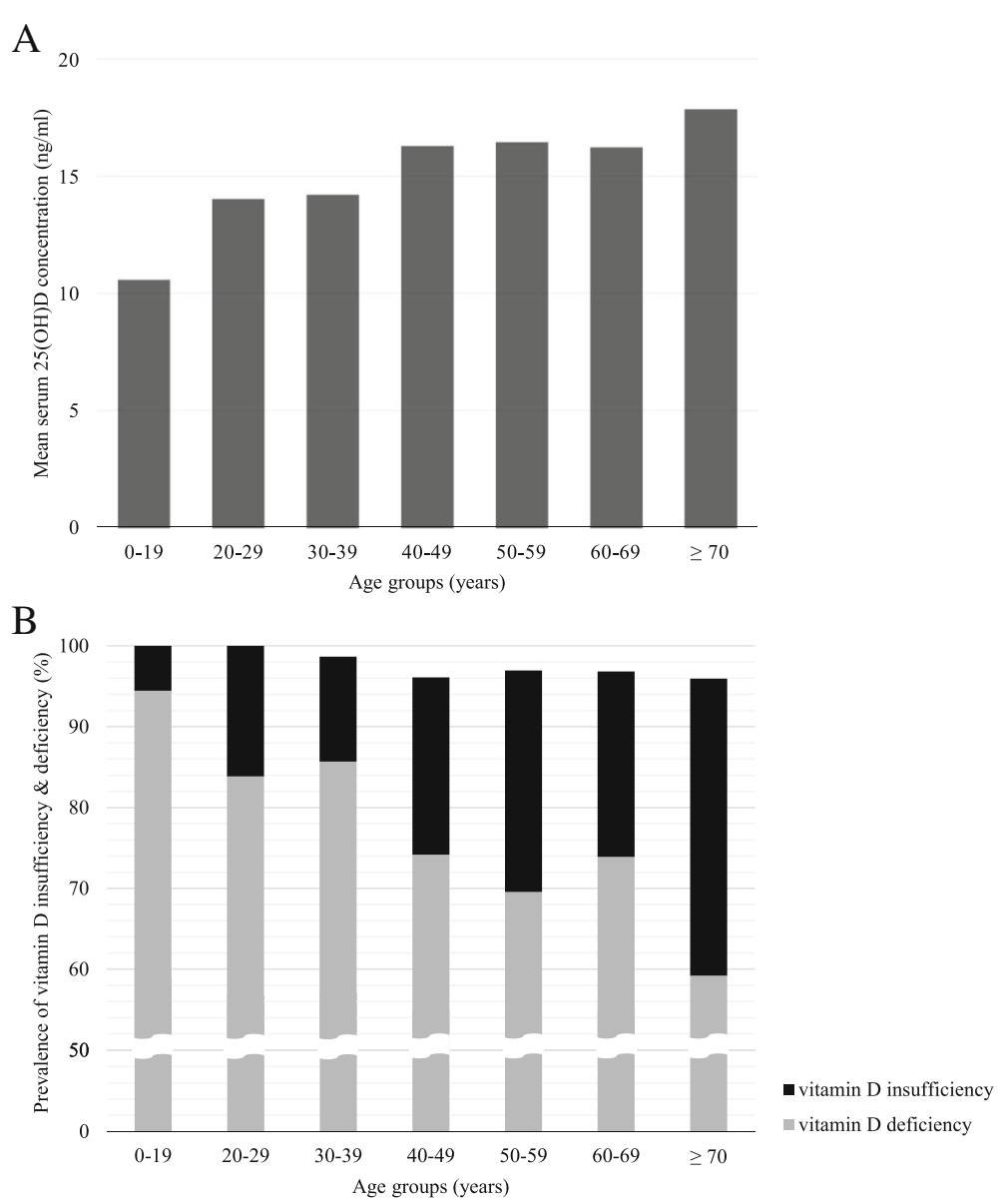

Fig. 2 a Distribution of mean serum 25-hydroxyvitamin $D[25(\mathrm{OH}) \mathrm{D}]$ concentration by age groups. When analyzed by linear regression, mean serum $25(\mathrm{OH}) \mathrm{D}$ concentration tended to increase with age $\left(R^{2}=0.032, p\right.$ for trend $\left.<0.001\right)$. $\mathbf{b}$ Prevalence of vitamin $\mathrm{D}$ insufficiency and deficiency by age groups. As participants' age increased, the prevalence of vitamin D deficiency tended to decrease. ( $p$ for trend $<$ 0.001 , obtained by linear-by-linear association of chi-square test)

Gender difference in vitamin D status is well known, with women generally showing lower mean serum vitamin $\mathrm{D}$ concentration than men $[14,25,26]$. One study done in Chinese adolescents showed gender difference in genetic influence on serum vitamin $\mathrm{D}$, arousing possibility of effect of factors associated with reproductivity on serum vitamin D concentration in females [14]. Moreover, many factors associated with bone metabolism were significantly different in their concentrations and genetic variance according to the menopausal status, probably due to change in estrogen level [15]. In our study, in order to eliminate the differential effect of sex and estrogen in vitamin D status and to focus on determining the genetic influence on vitamin $\mathrm{D}$, we excluded females.

Sun exposure is also known as one of the critical factors that affect serum vitamin $D$ concentration as the main source of vitamin D synthesis [4]. Therefore,

Table 2 Intraclass correlation coefficients between intrafamilial pairs and heritability of 25-hydroxyvitamin D

\begin{tabular}{|c|c|c|c|c|c|}
\hline \multirow[b]{2}{*}{ Models } & \multicolumn{3}{|c|}{ Intraclass correlation coefficients ( $95 \%$ Cl) } & \multirow[t]{2}{*}{$\mathrm{H}^{2}$ (SE) } & \multirow{2}{*}{$\begin{array}{l}\text { VAR } \\
\text { (\%) }\end{array}$} \\
\hline & $\begin{array}{l}\text { Between MZ twin pairs } \\
(n=146 \text { pairs })\end{array}$ & $\begin{array}{l}\text { Between sibling pairs } \\
(n=147 \text { pairs })\end{array}$ & $\begin{array}{l}\text { Between father-son pairs } \\
(n=266 \text { pairs })\end{array}$ & & \\
\hline Age-adjusted & $0.61(0.54-0.68)$ & $0.43(0.34-0.51)$ & $0.31(0.25-0.38)$ & $0.58(0.09)$ & 3.7 \\
\hline Model $1^{a}$ & $0.54(0.45-0.61)$ & $0.34(0.25-0.43)$ & $0.27(0.20-0.34)$ & $0.52(0.05)$ & 16.2 \\
\hline Model $2^{b}$ & $0.53(0.44-0.61)$ & $0.34(0.24-0.43)$ & $0.28(0.20-0.34)$ & $0.51(0.09)$ & 16.6 \\
\hline
\end{tabular}

$\mathrm{Cl}$ confidence interval, $\mathrm{MZ}$ monozygotic, $H^{2}$ (SE) heritability (standard error), VAR proportion of variance explained by covariates

an model 1, physical activity, multivitamin intake, and season were additionally adjusted from age-adjusted model

${ }^{\mathrm{b}}$ In model 2, smoking status and alcohol consumption were further added to model 1 
Table 3 Intraclass correlation coefficients between intrafamilial pairs and heritability of 25-hydroxyvitamin D, after exclusion of participants who reported on multivitamin usage

\begin{tabular}{|c|c|c|c|c|c|}
\hline \multirow[b]{2}{*}{ Models } & \multicolumn{3}{|c|}{ Intraclass correlation coefficients (95\% Cl) } & \multirow[t]{2}{*}{$\mathrm{H}^{2}(\mathrm{SE})$} & \multirow{2}{*}{$\begin{array}{l}\text { VAR } \\
(\%)\end{array}$} \\
\hline & $\begin{array}{l}\text { Between MZ twin pairs } \\
\text { ( } n=98 \text { pairs })\end{array}$ & $\begin{array}{l}\text { Between sibling pairs } \\
\text { ( } n=115 \text { pairs) }\end{array}$ & $\begin{array}{l}\text { Between father-son pairs } \\
\text { ( } n=167 \text { pairs) }\end{array}$ & & \\
\hline Age-adjusted & $0.57(0.47-0.66)$ & $0.46(0.36-0.55)$ & $0.35(0.27-0.43)$ & $0.44(0.10)$ & 4.0 \\
\hline Model $1^{\mathrm{a}}$ & $0.51(0.40-0.61)$ & $0.37(0.27-0.47)$ & $0.32(0.23-0.40)$ & $0.39(0.10)$ & 15.8 \\
\hline Model $2^{b}$ & $0.51(0.40-0.61)$ & $0.36(0.26-0.46)$ & $0.32(0.23-0.40)$ & $0.40(0.10)$ & 15.5 \\
\hline
\end{tabular}

$\mathrm{Cl}$ confidence interval, $M Z$ monozygotic, $H^{2}$ (SE) heritability (standard error), VAR proportion of variance explained by covariates

${ }^{a}$ In model 1, physical activity and season were additionally adjusted from age-adjusted model

${ }^{\mathrm{b}}$ In model 2, smoking status and alcohol consumption were further added to model 1

latitude may have great influence on vitamin D status $[4,27]$. Unfortunately, we did not consider the effect of latitude in our study due to the lack of information. However, we think that the amount of natural sunlight exposure by the effect of latitude is less likely to differ significantly among study participants given that our study participants reside in the area located between a narrow segment of latitude of $35^{\circ}$ and $38^{\circ}$. Instead, we included season of blood sampling and physical exercise (which may be relevant to the amount of sun exposure through outdoor activity) as covariates in the analyses. Physical activity was shown to be an important confounding factor in previous studies, although it cannot be considered as a proxy for outdoor sunlight exposure [8, 14]. Seasonal variation in serum $25(\mathrm{OH}) \mathrm{D}$ concentration due to change in UV B radiation was clearly observed in this study, consistent with findings from previous studies conducted in various areas around the world [7, 14, $16,19,28]$. Interestingly, we found that blood samples drawn in September, not in the summer season from June to August, showed the highest mean serum $25(\mathrm{OH}) \mathrm{D}$ concentration. This may be attributable to the fact that people go out and do more physical activity when it is not too hot [28].

Aging may lead to decreased synthesis of vitamin D inside the body since 7-decholecalciferol, the precursor of vitamin $\mathrm{D}_{3}$, tend to decrease in the skin of the elderly [29]. Moreover, as people get older, they are more likely to stay indoors due to difficulty in movement. Therefore, older people should have lower serum $25(\mathrm{OH}) \mathrm{D}$ concentration and higher prevalence of vitamin D deficiency than younger people. Although several studies have shown results supporting this assumption [9, 30-32], controversial findings have been found in different studies, including ours. In our study, we found that mean $25(\mathrm{OH}) \mathrm{D}$ concentration increased significantly and the prevalence of vitamin D deficiency decreased as participants' age increased. Similar findings have been shown in a study of Hovsepian et al., using data from Iranian healthy adults. They compared the vitamin D concentrations among three age groups: $20-39,40-59$, and $60-$
80 years [33]. Analyses using data from the NHANES of US population have reported inconsistent findings over time. An inverse relation between serum 25(OH)D concentration and age was found in the NHANES of 1988-1994, but not in the NHANES of 2001-2004 [9]. Significant difference in the prevalence of vitamin D deficiency across different age groups also disappeared in the study using data from NHANES of 2005-2006 [34]. Difference in health behavior of the elderly among diverse societies and change of this behavior over time may explain the inconsistency found in the relation between age and vitamin $\mathrm{D}$ status. As a society becomes more industrialized and wealthier, the elderly may have more interest in health-pursuing activities, including physical exercise, outdoor activities, and nutritional supplementation such as multivitamin, than younger people. However, we could not examine the validity of this hypothesis in the present study.

Smoking has negative effect on serum vitamin D concentration as shown in many previous studies. Smokers have lower mean serum 25(OH)D concentration and higher prevalence of vitamin $\mathrm{D}$ deficiency and insufficiency compared to non-smokers [35-39]. However, in our study, there was no specific relation between smoking and serum $25(\mathrm{OH}) \mathrm{D}$ concentration, although the proportion of current smokers was the lowest in the highest $25(\mathrm{OH}) \mathrm{D}$ tertile group. This unexpected finding could be related to the behavior of smokers under environmental regulation for smoking in Korea. That is, most smokers go outside to smoke, because indoor smoking is prohibited in Korea. This might have resulted in relative increase in the sunlight exposure of smokers [38].

Alcohol consumption is also known to be inversely associated with vitamin D status [40-42]. In our study, the proportion of current alcohol drinkers was the lowest in the highest $25(\mathrm{OH}) \mathrm{D}$ tertile group. However, there was no linear relationship between alcohol intake and $25(\mathrm{OH}) \mathrm{D}$ concentration.

In agreement with our study, many studies have shown significant genetic influence on vitamin D concentration in a person, although the estimated heritability ranged 
widely from $23 \%$ to $80 \%[8,14-20]$. Many genes and proteins involved in the metabolism and actions of vitamin $\mathrm{D}$ are known to affect the concentration of serum $25(\mathrm{OH}) \mathrm{D}$, resulting in individual and/or racial differences.

Vitamin D comes into the body or synthesized endogenously and metabolized into its active form and transported in circulation with its binding protein. Genetic alteration may happen in any of these steps, thus possibly altering serum $25(\mathrm{OH}) \mathrm{D}$ concentration [43]. From candidate gene studies and genome-wide association studies (GWAS) on vitamin D, several important genes and their single-nucleotide polymorphisms (SNPs) associated with difference in vitamin $D$ status have been discovered, including CYP2R1, CYP27B1, CYP24A1, GC, VDR, and NADSYN1/DHCR7 [44, 45]. CYP2R1 and CYP27B1 are cytochrome P450 enzymes known to function in the metabolism of vitamin $\mathrm{D}$ by converting vitamin $\mathrm{D}$ into its active form, $1 \alpha, 25(\mathrm{OH})_{2} \mathrm{D}$ [46]. Many studies have proven that mutations in these enzymes could alter serum 25(OH)D concentration [17, 43, 47-49]. GC gene encodes vitamin D carrier protein, known as DBP. Several SNPs in this gene have also shown significant association with serum 25(OH)D concentration in many studies performed in various ethnicities $[8,43,50,51]$. Vitamin $D$ receptor (VDR) is a high-affinity receptor for $1 \alpha, 25(\mathrm{OH})_{2} \mathrm{D}$. It acts as a transcription factor within the cell nucleus [52, 53]. Some genetic changes made in this gene are also associated with variations in serum vitamin D concentration $[17$, $54,55]$, possibly by changing the effectiveness of its transcription action [56]. From a recent large GWAS in European-ancestry participants, two additional loci at SEC23A and AMDHD1 genes were found and overall estimated heritability of serum $25(\mathrm{OH}) \mathrm{D}$ concentrations attributable to common genome-wide SNPs was modest (7.5\%) [57].

The heritability of serum $25(\mathrm{OH}) \mathrm{D}$ concentration tends to differ between different ethnic populations. Wjst et al. have reported that the heritability of $25(\mathrm{OH}) \mathrm{D}_{3}$ concentration in their study participants from German families is $80.3 \%$ [20]. The heritability of $25(\mathrm{OH}) \mathrm{D}$ concentration in Hispanic and African American families has been estimated to be 22.7 to $41.3 \%$, which is lower than that of Caucasians [8]. In Asian subjects, Arguelles et al. have reported that the heritability of $25(\mathrm{OH}) \mathrm{D}$ concentration is $68.9 \%$ in Chinese adolescent twins [14]. In our study of Korean male adults, the heritability of $25(\mathrm{OH}) \mathrm{D}$ concentration was estimated to be $51 \%$, which was lower than that of Caucasians, but higher than that of Hispanics or African Americans. Overall, results from these studies seem to suggest ethnical differences in genetic influence on vitamin $\mathrm{D}$ status. Robien et al. have reported that they could not reconfirm the associations of VDR or CYP27B1 genes with vitamin $\mathrm{D}$ concentration in Chinese adults living in Singapore, although such association is commonly found in studies conducted in white people [43]. Although the author of this study mentioned that difference in size of study population, latitude, and covariates used in the adjustment might be possible reasons for such racial discrepancy, ethnical differences in genetic regulation of vitamin $D$ cannot be excluded. However, more studies need to be conducted in various populations in order to find out the genetic basis of vitamin $\mathrm{D}$ regulation.

Another possible reason for the wide range of heritability reported in previous studies of genetic influence on vitamin $\mathrm{D}$ is difference in the season of blood sampling between studies. Karohl et al. have reported seasonal variability in the heritability of vitamin D concentration in US middle-aged White male twins: $70 \%$ in the winter time and $0 \%$ in the summer time [16]. A study conducted in Swedish adult twins by Snellman et al. has also documented seasonal variation in the heritability of serum $25(\mathrm{OH}) \mathrm{D}$ concentration, although the result pointed at an opposite direction: heritability of $48 \%$ in the summer and $0 \%$ in the winter [19]. In any case, there seems to be a genetically important factor at the stage of cutaneous synthesis that is influenced by the amount of UV B radiation [16, 19]. Further research is needed in this area.

This study has some limitations. First, a cross-sectional study design cannot establish the causal association. Therefore, cautious interpretation for the association between factors and vitamin $\mathrm{D}$ concentration in the present study is needed. Second, we only included adult males. Therefore, findings of our study cannot be applied to women, children, or adolescents. Thirdly, we were not able to measure the exact amount of vitamin D intake or outdoor activity, which could result in bias. However, when we conducted sensitivity analysis after excluding multivitamin users, significant heritability persisted with only slight diminution.

\section{Conclusions}

In conclusion, hypovitaminosis D was highly prevalent in Korean men and the estimated heritability of serum $25(\mathrm{OH}) \mathrm{D}$ was moderately high. These findings suggest that genetic factors play significant roles in determining the vitamin $\mathrm{D}$ status in a person. Further study is warranted to identify specific genes involved.

\section{Additional file}

Additional file 1: Study participants flowchart. (PDF 52 kb)

\footnotetext{
Abbreviations

25(OH)D: 25-Hydroxyvitamin D; BMI: Body mass index; Cl: Confidence interval; GWAS: Genome-wide association study; ICC: Intraclass correlation coefficient; KNHANES: Korean National Health and Nutritional Examination Survey; NHANES: National Health and Nutrition Examination Survey; SD: Standard deviation; SE: Standard error; SNP: Single-nucleotide polymorphism
} 


\section{Acknowledgements}

Not applicable.

\section{Funding}

This research was supported by the Basic Science Research Program through the National Research Foundation of Korea (NRF) funded by the Ministry of Science, ICT and future Planning (2014R1A2A2A01002705).

\section{Availability of data and materials}

The datasets used and analyzed during the current study are available from the corresponding author on reasonable request.

\section{Authors' contributions}

SC designed and conducted the research, analyzed the data, and was a major contributor in writing the manuscript. HK analyzed the data. Y-MS reviewed the manuscript and advised on relevant statistical analyses. KL and JS managed the database and were primary investigators on Healthy Twin Study that formed the basis of present study. All authors read and approved the final manuscript.

\section{Ethics approval and consent to participate}

Written informed consent was obtained from all participants of this study The study protocol was approved by the Institutional Review Board at the Samsung Medical Center and Seoul National University School of Public Health.

\section{Consent for publication}

Not applicable.

\section{Competing interests}

All authors declare that they have no competing interests.

\section{Publisher's Note}

Springer Nature remains neutral with regard to jurisdictional claims in published maps and institutional affiliations.

\section{Author details}

'Department of Family Medicine, Samsung Medical Center, Sungkyunkwan University School of Medicine, Irwon-ro 81, Gangnamgu, Seoul 06351 135-710, South Korea. ${ }^{2}$ Health Screening Center Kangbuk Samsung Hospital, Sungkyunkwan University School of Medicine, Seoul 03181, South Korea. ${ }^{3}$ Department of Family Medicine, College of Medicine, Busan Paik Hospital, Inje University, Busan 47392, South Korea. ${ }^{4}$ Department of Epidemiology, School of Public Health and Institute of Health Environment, Seoul National University, Seoul 03080, South Korea.

Received: 14 May 2018 Accepted: 29 November 2018

Published online: 19 December 2018

\section{References}

1. Giovannucci E, Liu Y, Rimm EB, Hollis BW, Fuchs CS, Stampfer MJ, Willett WC. Prospective study of predictors of vitamin D status and cancer incidence and mortality in men. J Natl Cancer Inst. 2006;98(7):451-9.

2. Zittermann A. Vitamin $D$ and disease prevention with special reference to cardiovascular disease. Prog Biophys Mol Biol. 2006;92(1):39-48.

3. Gorham ED, Garland CF, Garland FC, Grant WB, Mohr SB, Lipkin M, Newmark HL, Giovannucci E, Wei M, Holick MF. Vitamin D and prevention of colorectal cancer. J Steroid Biochem Mol Biol. 2005;97(1-2):179-94.

4. Holick MF, Chen TC. Vitamin D deficiency: a worldwide problem with health consequences. Am J Clin Nutr. 2008;87(suppl):1080S-6S

5. Holick MF. Vitamin D: importance in the prevention of cancers, type diabetes, heart disease, and osteoporosis. Am J Clin Nutr. 2004;79:362-71.

6. Holick MF. Vitamin D Deficiency. NEJM. 2007;357(3):266-81.

7. Ganji V, Zhang X, Tangpricha V. Serum 25-hydroxyvitamin D concentrations and prevalence estimates of hypovitaminosis $D$ in the U.S. population based on assay-adjusted data. J Nutr. 2012;142(3):498-507.

8. Engelman CD, Fingerlin TE, Langefeld CD, Hicks PJ, Rich SS, Wagenknecht $L E$, Bowden DW, Norris JM. Genetic and environmental determinants of 25hydroxyvitamin D and 1,25-dihydroxyvitamin D levels in Hispanic and African Americans. J Clin Endocrinol Metab. 2008;93(9):3381-8.
9. Ginde AA, Liu MC, Camargo CA Jr. Demographic differences and trends of vitamin D insufficiency in the US population, 1988-2004. Arch Intern Med. 2009;169(6):626-32.

10. Zadshir A, Tareen N, Pan D, Norris K, Martins D. The prevalence of hypovitaminosis D among US adults: data from the NHANES III. Ethn Dis. 2005;15:S5-97-101.

11. Welfare MoH. Korea Health Statistics 2010 : Korea National Health and Nutrition Examination Survey (KNHANES V-1). Seoul: Ministry of Health and Welfare; 2011

12. Yu S, Fang H, Han J, Cheng X, Xia L, Li S, Liu M, Tao Z, Wang L, Hou L, et al. The high prevalence of hypovitaminosis $D$ in China: a multicenter vitamin $D$ status survey. Medicine (Baltimore). 2015;94(8):e585.

13. Yoshimura N, Muraki S, Oka H, Morita M, Yamada H, Tanaka S, Kawaguchi H, Nakamura K, Akune T. Profiles of vitamin D insufficiency and deficiency in Japanese men and women: association with biological, environmental, and nutritional factors and coexisting disorders: the ROAD study. Osteoporos Int. 2013;24:2775-87.

14. Arguelles LM, Langman CB, Ariza AJ, Ali FN, Dilley K, Price H, Liu X, Zhang S, Hong $X$, Wang $B$, et al. Heritability and environmental factors affecting vitamin D status in rural Chinese adolescent twins. J Clin Endocrinol Metab. 2009:94(9):3273-81.

15. Hunter $D$, De Lange M, Snieder H, MacGregor AJ, Swaminathan $R$, Thakker RV, Spector TD. Genetic contribution to bone metabolism, calcium excretion, and vitamin $\mathrm{D}$ and parathyroid hormone regulation. J Bone Miner Res. 2001:16(2):371-8.

16. Karohl C, Su S, Kumari M, Tangpricha V, Veledar E, Vaccarino V, Raggi P. Heritability and seasonal variability of vitamin $D$ concentrations in male twins. Am J Clin Nutr. 2010;92(6):1393-8.

17. Orton SM, Morris AP, Herrera BM, Ramagopalan SV, Lincoln MR, Chao MJ, Vieth $R$, Sadovnick AD, Ebers GC. Evidence for genetic regulation of vitamin D status in twins with multiple sclerosis. Am J Clin Nutr. 2008:88(2):441-7.

18. Shea MK, Benjamin EJ, Dupuis J, Massaro JM, Jacques PF, D'Agostino RB Sr, Ordovas JM, O'Donnell CJ, Dawson-Hughes B, Vasan RS, et al. Genetic and non-genetic correlates of vitamins K and D. Eur J Clin Nutr. 2009;63(4):458-64.

19. Snellman G, Melhus H, Gedeborg R, Olofsson S, Wolk A, Pedersen NL, Michaelsson K. Seasonal genetic influence on serum 25-hydroxyvitamin D levels: a twin study. PLoS One. 2009:4(11):e7747.

20. Wist M, Altmuller J, Braig C, Bahnweg M, Andre E. A genome-wide linkage scan for 25-OH-D(3) and 1,25-(OH)2-D3 serum levels in asthma families. J Steroid Biochem Mol Biol. 2007;103(3-5):799-802.

21. Sung J, Cho Sl, Lee K, Ha M, Choi EY, Choi JS, Kim H, Kim J, Hong KS, Kim Y, et al. Healthy twin: a twin-family study of Korea--protocols and current status. Twin Res Hum Genet. 2006;9(6):844-8.

22. Song YM, Lee D, Lee MK, Lee K, Lee HJ, Hong EJ, Han B, Sung J. Validity of the zygosity questionnaire and characteristics of zygosity-misdiagnosed twin pairs in the Healthy Twin Study of Korea. Twin Res Hum Genet. 2010; 13(3):223-30.

23. Almasy L, Blangero J. Multipoint quantitative-trait linkage analysis in general pedigrees. Am J Hum Genet. 1998;62(5):1198-211.

24. Williams JT, Blangero J. Comparison of variance components and sibpairbased approaches to quantitative trait linkage analysis in unselected samples. Genet Epidemiol. 1999;16(2):113-34.

25. Bolland MJ, Grey AB, Ames RW, Horne AM, Mason BH, Wattie DJ, Gamble GD, Bouillon R, Reid IR. Age-, gender-, and weight-related effects on levels of 25-hydroxyvitamin $\mathrm{D}$ are not mediated by vitamin $\mathrm{D}$ binding protein Clin Endocrinol. 2007;67(2):259-64.

26. Verdoia M, Schaffer A, Barbieri L, Di Giovine G, Marino P, Suryapranata H, De Luca G, Novara Atherosclerosis Study. Impact of gender difference on vitamin D status and its relationship with the extent of coronary artery disease. Nutr Metab Cardiovasc Dis. 2015;25(5):464-70.

27. Chen TC, Chimeh F, Lu Z, Mathieu J, Person KS, Zhang A, Kohn N, Martinello S, Berkowitz R, Holick MF. Factors that influence the cutaneous synthesis and dietary sources of vitamin D. Arch Biochem Biophys. 2007;460(2):213-7.

28. Nah EH, Kim S, Cho H-I. Vitamin D levels and prevalence of vitamin D deficiency associated with sex, age, region, and season in Koreans. Lab Med Online. 2015:5(2):84.

29. Holick MF, Matsuoka LY, Wortsman J. Age, vitamin D, and solar ultraviolet. Lancet (London, England). 1989;2(8671):1104-5.

30. Lips P. Vitamin D deficiency and secondary hyperparathyroidism in the elderly: consequences for bone loss and fractures and therapeutic implications. Endocr Rev. 2001;22(4):477-501. 
31. Mithal A, Wahl DA, Bonjour JP, Burckhardt P, Dawson-Hughes B, Eisman JA, ElHajj Fuleihan G, Josse RG, Lips P, Morales-Torres J. Global vitamin D status and determinants of hypovitaminosis D. Osteoporos Int. 2009;20(11):1807-20.

32. Burnand B, Sloutskis D, Gianoli F, Cornuz J, Rickenbach M, Paccaud F, Burckhardt P. Serum 25-hydroxyvitamin D: distribution and determinants in the Swiss population. Am J Clin Nutr. 1992:56(3):537-42.

33. Hovsepian S, Amini M, Aminorroaya A, Amini P, Iraj B. Prevalence of vitamin D deficiency among adult population of Isfahan City, Iran. J Health Popul Nutr. 2011;29(2):149-55.

34. Forrest $K Y$, Stuhldreher WL. Prevalence and correlates of vitamin D deficiency in US adults. Nutr Res. 2011;31(1):48-54.

35. Supervia A, Nogues X, Enjuanes A, Vila J, Mellibovsky L, Serrano S, Aubia J, Diez-Perez A. Effect of smoking and smoking cessation on bone mass, bone remodeling, vitamin D, PTH and sex hormones. J Musculoskelet Neuronal Interact. 2006;6(3):234-41.

36. Shinkov A, Borissova AM, Dakovska L, Vlahov J, Kassabova L, Svinarov D. Winter 25-hydroxyvitamin D levels in young urban adults are affected by smoking, body mass index and educational level. Eur J Clin Nutr. 2015;69(3):355-60.

37. Kassi EN, Stavropoulos S, Kokkoris P, Galanos A, Moutsatsou P, Dimas C, Papatheodorou A, Zafeiris C, Lyritis G. Smoking is a significant determinant of low serum vitamin $D$ in young and middle-aged healthy males. Hormones (Athens, Greece). 2015;14(2):245-50.

38. Jiang $C Q$, Chan $Y H$, Xu L, Jin YL, Zhu T, Zhang WS, Cheng KK, Lam TH. Smoking and serum vitamin D in older Chinese people: cross-sectional analysis based on the Guangzhou Biobank Cohort Study. BMJ Open. 2016; 6(6):e010946.

39. Brot $\mathrm{C}$, Jorgensen $\mathrm{NR}$, Sorensen $\mathrm{OH}$. The influence of smoking on vitamin $\mathrm{D}$ status and calcium metabolism. Eur J Clin Nutr. 1999;53(12):920-6.

40. Lee K. Sex-specific relationships between alcohol consumption and vitamin D levels: the Korea National Health and Nutrition Examination Survey 2009. Nutr Res Pract. 2012;6(1):86-90.

41. Leevy CM, Moroianu SA. Nutritional aspects of alcoholic liver disease. Clin Liver Dis. 2005;9(1):67-81.

42. Ogunsakin O, Hottor T, Mehta A, Lichtveld M, McCaskill M. Chronic ethanol exposure effects on Vitamin D levels among subjects with alcohol use disorder. Environ Health Insights. 2016;10:191-9.

43. Robien K, Butler LM, Wang R, Beckman KB, Walek D, Koh WP, Yuan JM. Genetic and environmental predictors of serum 25-hydroxyvitamin D concentrations among middle-aged and elderly Chinese in Singapore. $\mathrm{Br}$ J Nutr. 2013;109(3):493-502.

44. Ahn J, Yu K, Stolzenberg-Solomon R, Simon KC, McCullough ML, Gallicchio

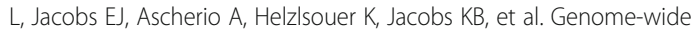
association study of circulating vitamin D levels. Hum Mol Genet. 2010; 19(13):2739-45.

45. Wang TJ, Zhang F, Richards JB, Kestenbaum B, van Meurs JB, Berry D, Kiel DP, Streeten EA, Ohlsson C, Koller DL, et al. Common genetic determinants of vitamin D insufficiency: a genome-wide association study. Lancet. 2010; 376(9736):180-8.

46. Dastani Z, Li R, Richards B. Genetic regulation of vitamin D levels. Calcif Tissue Int. 2013;92(2):106-17.

47. Cheng JB, Levine MA, Bell NH, Mangelsdorf DJ, Russell DW. Genetic evidence that the human CYP2R1 enzyme is a key vitamin D 25hydroxylase. Proc Natl Acad Sci U S A. 2004;101(20):7711-5.

48. Ramos-Lopez E, Kahles H, Weber S, Kukic A, Penna-Martinez M, Badenhoop K, Louwen F. Gestational diabetes mellitus and vitamin D deficiency: genetic contribution of CYP27B1 and CYP2R1 polymorphisms. Diabetes Obes Metab. 2008;10(8):683-5.

49. Signorello LB, Shi J, Cai Q, Zheng W, Williams SM, Long J, Cohen SS, Li G, Hollis BW, Smith JR, et al. Common variation in vitamin D pathway genes predicts circulating 25-hydroxyvitamin D levels among African Americans. PLoS One. 2011;6(12):e28623.

50. Kurylowicz A, Ramos-Lopez E, Bednarczuk T, Badenhoop K. Vitamin Dbinding protein (DBP) gene polymorphism is associated with Graves' disease and the vitamin D status in a Polish population study. Exp Clin Endocrinol Diabetes. 2006;114(6):329-35.

51. Lu L, Sheng H, Li H, Gan W, Liu C, Zhu J, Loos RJ, Lin X. Associations between common variants in GC and DHCR7/NADSYN1 and vitamin D concentration in Chinese Hans. Hum Genet. 2012;131(3):505-12.

52. Haussler MR, Haussler CA, Jurutka PW, Thompson PD, Hsieh JC, Remus LS, Selznick SH, Whitfield GK. The vitamin D hormone and its nuclear receptor: molecular actions and disease states. J Endocrinol. 1997;154(Suppl):S57-73.
53. Carlberg C. Genome-wide (over)view on the actions of vitamin D. Front Physiol. 2014;5:167.

54. d'Alesio A, Garabedian M, Sabatier JP, Guaydier-Souquieres G, Marcelli C, Lemacon A, Walrant-Debray O, Jehan F. Two single-nucleotide polymorphisms in the human vitamin D receptor promoter change proteinDNA complex formation and are associated with height and vitamin D status in adolescent girls. Hum Mol Genet. 2005;14(22):3539-48.

55. Smolders J, Damoiseaux J, Menheere P, Tervaert JW, Hupperts R. Fok-I vitamin D receptor gene polymorphism (rs10735810) and vitamin D metabolism in multiple sclerosis. J Neuroimmunol. 2009;207(1-2):117-21.

56. Arai H, Miyamoto Kl, Yoshida M, Yamamoto H, Taketani Y, Morita K, Kubota M, Yoshida S, Ikeda M, Watabe F, et al. The polymorphism in the caudalrelated homeodomain protein $\mathrm{Cdx}-2$ binding element in the human vitamin D receptor gene. J Bone Miner Res. 2001;16(7):1256-64.

57. Jiang X, O'Reilly PF, Aschard H, Hsu YH, Richards JB, Dupuis J, Ingelsson E, Karasik D, Pilz S, Berry D, et al. Genome-wide association study in 79,366 European-ancestry individuals informs the genetic architecture of 25hydroxyvitamin D levels. Nat Commun. 2018;9(1):260.

\section{Ready to submit your research? Choose BMC and benefit from:}

- fast, convenient online submission

- thorough peer review by experienced researchers in your field

- rapid publication on acceptance

- support for research data, including large and complex data types

- gold Open Access which fosters wider collaboration and increased citations

- maximum visibility for your research: over $100 \mathrm{M}$ website views per year

At BMC, research is always in progress.

Learn more biomedcentral.com/submissions 